\title{
ANALYZING CONSTITUTIONS
}

\author{
PETER M.SHANE
}

Constitutions, written or unwritten, are sets of rules, practices, and customs that polities regard as their fundamental law (DeSmith and Brazier 1989:3-4). In modern form, they typically aspire to constrain government power, assure adherence to the rule of law, and protect individual rights (Rosenfeld 1994: 3). As such, they fit Douglass North's conception of an institution as a socially imposed constraint or set of constraints upon human behavior (North 1990: 3). Of course, in their variety and significance, they pose questions of obvious interest to political scientists, sociologists, and legal scholars. Some of these questions are comparative in nature: Why do different constitutions take the different forms they do? What political or other differences do distinctions in constitutional form and substance actually make? (e.g. Sartori 1994). Other questions can be sensibly asked with regard to constitutions in general or particular constitutions as they operate in particular societies: What are the social and political functions of a constitution? Through what social and political processes are the provisions of a constitution actually translated into meaningful constraints or authorities? This chapter offers a perspective on constitutional analysis that examines these latter questions, largely through an American lens.

Because constitutions, written or unwritten, can be given operational meaning only through the workings of other political institutions, any analysis of how constitutions shape and facilitate human interaction must necessarily be complex. In the United States, it is impossible to speak sensibly of "what the Constitution 
does" without reference to its invocation and use by the three branches of federal and state governments, as well as by local political entities and even by the organizations of civil society. This fact, however, entails an additional complexity. The primary human activity through which constitutions are translated into operational authorizations or constraints is interpretation. Yet, the available research on constitutional interpretation-most of which focuses on the operation of constitutional interpretation in the United States Supreme Court-tends to fall into two very disparate perspectives on the nature of the interpretive enterprise.

The two distinct views may helpfully be referred to "internal" and "external" (Feldman 2005: 89-90.) According to the "internal view," what legal materials say-that is, the history and wording of constitutions, statutes, prior judicial opinions, and so on-significantly determines how they are interpreted. Under this view, when lawyers and judges give operational meaning to constitutions, statutes, and legal precedents, they are meaningfully limited by what can logically be deduced from the rules and principles that emanate from such legal materials (Feldman 2005). Although there is probably no one who thinks that those limits offer a complete explanation for all of the behavior of all legal actors, it is a premise of most modern legal scholarship that the internal view is, to some significant degree, well-founded.

In contrast, according to the external view, what governs the behavior of legal actors are stimuli external to the legal materials themselves (Feldman 2005). Chief among them are the actors' political orientations, namely, preferences or ideologies that, depending on the model, may follow from any number of causes-economic or political self-interest being the most obvious (Segal and Spaeth 1993: 64-9). This is undoubtedly the predominant view among political scientists (Feldman 2005: 90). One meta-analysis of over eighty papers has found a robust association between judicial decisions and judicial political attitudes across legal issues, courts systems, and statistical method of analysis (Pinello 1999). Thus, in the external view, what a judge decides may be rationalized in the language of law, but it is not the law that produces outcomes, but other sources of judicial attitude.

An accurate picture almost certainly requires a perspective that draws on both these views. A significant ongoing project among legal researchers is the attempt to produce an "internal" view that affords legitimate room for legal actors to involve their personal political and moral values in an appropriately channeled and therefore legitimate manner in constitutional interpretation (e.g. Feldman 2005; Dworkin 1996). Among political scientists, perhaps the most exciting new development is the "new institutionalism," an effort to show how the attitudes of legal actors, especially judges, are shaped not only by individual preference, but also by the institutions through which these actors operate and the relationship of those institutions to others. Leading writers in this vein include Cornell Clayton, Howard Gillman, Mark Graber, Rogers Smith and Keith Whittington (Gillman 1993; Gillman and Clayton 1999; Graber 2002; Smith 1988; Whittington 2000). 
These complementary lines of analysis reflect an admirable effort to get beyond reductionist models of law that either treat legal interpretation as implausibly objective and mechanical or reduce law to something merely obfuscatory or "epiphenomenal" (Feldman 2005: 92).

\section{The Status and Function of ConstituTiONS}

In the American public law system, a constitution is invariably fundamental in the sense that a government act undertaken pursuant to a state or federal constitution is expected to conform to its requirements and limitations. Since the revolutionary period, this essential characteristic of American constitutions, both state and federal, has been regarded as flowing inexorably from their written character. ${ }^{1}$ Other systems, most notably that of Great Britain, may feature a constitutional doctrine of parliamentary supremacy, in which the constitution imposes no more than theoretical limits on legislative acts (DeSmith and Brazier 1989: 15). Even in such systems, however, courts may presume an ordinary parliamentary intention not to depart from the constitution, written or unwritten, and may limit the reach of legislative measures through judicial interpretation designed to reconcile parliamentary acts with judicially inferred constitutional constraints (Krotoszynski 1994: 7-11).

In the American and other systems where a constitution is understood to constrain legislative action, constitutions will differ with regard to how easy they are to change and with respect to the authorities empowered to interpret whether government conformity to the constitution has been achieved. For example, state constitutions in the United States are frequently easy to amend by popular referendum (Marks and Cooper 2003: 300-14). Internationally, part of what makes the United States Constitution distinctive is that it is difficult to amend formally, and yet, from near the beginning, it has been interpreted as vesting in ordinary courts of general jurisdiction the power to determine whether government acts violate the Constitution and thus may be set aside. The easy availability of judicial review may seem yet more notable as compared to other legal systems because, at the federal level, American judges involved are presidential appointees with lifetime tenure and no direct electoral accountability.

There are at least four ways in which constitutions may be thought to shape or facilitate the actions of government institutions or of citizens themselves-

1 Marbury vs. Madison, 1 Cranch (5 U.S.) 137, 177 (1803). 
implementing the political bargains that make nation-building possible, structuring the exercise of government power, limiting the exercise of government power, and creating affirmative obligations of government to the citizenry.

\section{Implementing Key Founding Bargains}

Americans tend to pay greatest attention to those constitutional provisions that articulate deeply-held value commitments, such a free speech or due process, or implement what we take to be enduring principles of institutional design, such as the separation of powers. Constitutions, however, typically include at least some features that do not fall into either category. That is because, when a written constitution is drafted concurrently with the formation of a new regime or nation-state, it is likely that the document will be formulated, in part, to entrench particular political bargains, often messy ones, that were essential to regime formation. In the case of the United States, the subjects of the key bargains are well known. One was the fear of smaller states, especially states without good ports, that their interests would be overlooked or subordinated in a union with their more powerful neighbors. The second was slavery.

Because of the original small-state concerns, the United States Constitution continues to entrench most forcefully its most deeply anti-democratic provision, namely, the design of a federal upper legislative House with two members for every state, regardless of size. Although the United States Constitution is always difficult to amend, typically requiring two-thirds of each House of Congress to propose an amendment and ratification by three-fourths of the states, the small states' hold on the Senate is protected by the additional provision in Article V that "no state, without its consent, shall be deprived of its equal suffrage in the Senate." As a consequence, the United States seems to be stuck permanently with a Senate in which a majority of Senators routinely represent a minority of US voters (Shane 2003: 539). Furthermore, under Article I, section 10, states are not allowed, without consent of Congress, to "lay any imposts or duties on imports or exports," or to "enter into any agreement of compact with another state," thus providing small states yet further protection from predation by their larger neighbors.

Yet more ignominious bargains were struck, however, because of slavery. Although the words "slave" and "slavery" never appear in the document-a gesture to the free states' sensibilities-the Constitution prohibited Congress from stopping or even taxing the international slave trade prior to 1808 (Art. I, $\S$ 9). It credited the slave states, for purposes of legislative apportionment, with a 
population that included three-fifths of their slaves (Art. I, $\$ 2$ ). The Article on constitutional amendment protected the twenty-year slave trade "window" by prohibiting any amendments that would shorten it (Art. V). The Constitution still includes text providing that no state may enact laws purporting to discharge from "service or labor" any person who escapes to that state from another in which they are lawfully "held to service or labor" (Art. IV, \$2). Instead, any such escapee "shall be delivered up on claim of the party to whom such service or labor may be due" (Art. IV, \$2). Over the long term, these attempts to mediate the interests of free and slave states through law proved unavailing without war, and yet, it is certainly true that, without the initial bargains, no national union spanning the full east coast of the present-day United States would have been possible.

Idiosyncratic constitutional arrangements reflecting merely the political exigencies of a founding era can bedevil the enterprise of constitutional interpretation. Contemporary constitutional scholars along with numerous civil society groups often argue, for example, that the United States Constitution ought to be interpreted in light of what is taken to be a fundamental commitment in that document to the value of democracy (e.g., Ely 1980.) But, given the entrenched Senate structure, the exclusion of DC residents from voting representation in Congress and the arcane machinery of the presidential election process - each of which is a constitutional response to some eighteenth-century political anxiety that may no longer be salient-it may seem difficult to give the Constitution any coherent democratic reading. Moreover, political interests that still draw strength from these provisions are likely to prevent their change.

\section{Structuring the Exercise of Power}

At a more general level, it is, of course, the function of the United States Constitution, and presumably of all constitutions, to create the basic skeleton of offices and official processes through which government power shall be exercised, as well as the processes through which officeholders shall be selected. In structuring the allocation of government authority, the United States Constitution is generally described as embodying two fundamental government design principles, around which its more particularized provisions are oriented: federalism and the separation of powers. Federalism describes the allocation of power to both federal and state authorities, motivated by two general goals: a federal governmental competence adequate to address national challenges and protection for the governmental prerogatives of the states, which are regarded as closer to and 
more accountable to the people. The separation-of-powers principle likewise aims to implement a balance of virtues: the protection against tyranny deemed to result from assuring that the power to make, implement, and interpret law is largely vested in different institutions, and the greater efficiency and effectiveness thought to follow from focusing each branch's attention on tasks especially suited to its composition and processes (Fisher 1971).

With regard to a number of these key details of organization and process, the Constitution is sufficiently explicit so that few occasions have arisen calling for further interpretation. Yet, on a host of critical issues, the provisions through which the founders articulated their designs for federalism and separation of powers have proved highly ambiguous. These ambiguities have helped to sustain over two centuries of controversy largely because the purposes underlying the design principles are themselves notably in tension.

With regard to federalism, for example, the overriding question has been whether to regard the achievement of national competence or the insulation of state sovereignty as the primary value. ${ }^{2}$ Debates have been especially heated with regard to the scope of the clause that authorizes Congress to regulate "commerce with foreign nations, and among the several states" (Art. I, $₫ 8$ ). Many Supreme Court Justices, especially since the New Deal, have regarded the so-called Commerce Clause as embodying the framers' desire that Congress have sufficient authority to deal with virtually all social and economic problems of national scope. Such Justices would extend Congress's commerce power to include the direct regulation of interstate commercial activity for virtually any purpose, as well as the regulation of virtually any activity-local or not, commercial or notthat, taken in the aggregate, could have a significant effect on interstate commerce. ${ }^{3}$ Yet other Justices are concerned that, read in this way, Congress's authority under the Commerce Clause could be expanded to obliterate what they regard as a fundamental constitutional commitment to primary state control over issues of health, safety, and public welfare and morals. For such Justices, Congress may regulate local or non-commercial activities that substantially affect interstate

2 A closely related, but analytically distinct debate concerns the role of courts in enforcing whatever federalism principles are embodied in the Constitution. In a much-noted article, Herbert Wechsler argued in the 1950 s that the drafters of the Constitution intended the constitutional values of federalism to be protected chiefly through the structure and operation of the federal system itself and the elected branches of the federal government (Wechsler 1954). Significant entries in the nowmountainous literature on this subject include: Calabresi 1995; Choper 1980; Kramer 2000; LaPierre 1982; McConnell 1987; Marshall 1998; Rubin and Feeley 1994; Shapiro 1995; Van Alstyne 1985; and Yoo 1997. Interestingly, debates over the substantive values underlying federalism do not fall reliably on a conservative-liberal access. For significantly contrasting views on the value of federalism by two constitutional liberals, see Chemerinsky (1995) and Merritt (1994).

${ }^{3}$ For one of many strong judicial statements to this effect, see Justice Thurgood Marshall's opinion for the majority in Hodel vs. Virginia Surface Mining and Reclamation Association, 452 U.S. 254, 276-82 (1981), upholding federal strip mining standards. 
commerce only if such activities relate to commerce in a sufficiently distinct way that their regulation would still leave intact the states' traditional areas of sovereignty. 4

The search for balance between these views may prove elusive, even for a single Court. Thus, for example, in 1995, the Supreme Court held, in a 5-4 vote, that Congress overreached its authority in purporting to criminalize the knowing possession of a firearm in a so-called local "school zone." ${ }^{5}$ Despite the obvious linkage between threats of gun violence and the quality of education, and between the quality of education and the robustness of the interstate economy, the majority found such reasoning too attenuated to support the regulation of behavior that had nothing by itself to do with commerce or economic activity. ${ }^{6}$ By contrast, just ten years later, a different majority of six Justices held that Congress could regulate the local growth and possession of marijuana for purely medicinal purposes, on the ground that such a prohibition was integral to a comprehensive effort to eliminate the national market in marijuana. ${ }^{7}$ A compelling jurisprudential distinction between the cases is not easy to spot.

A similar sort of debate has bedeviled the development of constitutional jurisprudence regarding the separation of powers. For proponents of what might be called a "pluralist" view of this aspect of constitutional design-prominent examples include Cynthia Farina, Martin Flaherty, Abner Greene, Thomas Sargentich, Peter Shane, and Peter Strauss - the primary goal is to restrain the exercise of government power by allowing each branch to "check" and "balance" the initiatives of the other two branches (Farina 1998; Flaherty 1996; Greene 1994; Sargentich 1993; Shane 1995). By recognizing the overlapping powers of multiple authorities, this theory emphasizes the framers' desire for a pluralist consensus in the making of public policy. The contrasting view suggests that the key to separation of powers is the right of each branch to maintain its authorities inviolate against the initiatives of the other two branches. Champions of the latter view, including Steven Calabresi, Elena Kagan, Lawrence Lessig, Geoffrey Miller, Saikrishna Prakash, and Cass Sunstein, generally advance an ambitious vision of executive power under the Constitution, and thus the modern-day version of this stance can accurately be called "presidentialist" (Calabresi and Prakash 1994; Kagan 2001; Lessig and Sunstein 1994; Miller 1986).

The United States Constitution generally erects only the most basic scaffolding for the system by which the government's public officers are chosen. Federal judges, as noted above, are appointed by the President, pursuant to the advice and consent

\footnotetext{
4 United States vs. Lopez, 514 U.S. 549, 565 (1995) (invalidating federal statute prohibiting possession of guns within so-called "school zones").

5 United States vs. Lopez, 514 U.S. 549, 565 (1995)

6 United States vs. Lopez at 564.

7 Gonzales vs. Raich, 125 S. Ct. 2195 (2005).
} 
of the Senate, and hold lifetime tenure, subject only to impeachment (Shane, 1993). Originally, three modes of selection were employed for the elected branches: direct popular election for members of the House of Representatives, election by state legislatures for members of the Senate, and presidential selection through an elaborate scheme of federal electors, who were themselves to be chosen through processes specified by the respective legislatures of every state. It was not until 1913 that the Constitution was amended to provide for the popular election of Senators, but the torturous process for choosing presidents remains intact, largely because it favors the smaller states, which are sufficient in number to have defeated, so far, all attempts to amend the process (Edwards 2004).

The scheme of presidential election is a poignant example of how institutional responses to founding era anxieties can outlive their salience. The decision to vest presidential election power in dispersed groups of state electors chosen under a variety of differing state rules is sometimes portrayed as a deliberate and principled attempt to further the American constitutional commitment to federalism (Best 2004). This is not so. The so-called "electoral college" system was a largely undiscussed compromise that resulted after the drafters rejected the two options they quite consciously did not want: direct popular election or selection by Congress (Rakove 2004). It was anxieties about mass democracy and about subordinating federal executive authority to federal legislative power that motivated the adoption of America's idiosyncratic system. For all the influence the United States Constitution has had on subsequent efforts, no other country has adopted the electoral college.

\section{Limiting THE EXERCISE OF GovernMent Power}

Beyond its affirmative allocations of government power and specifications of offices and processes by which that power shall be exercised, the Constitution also limits the exercise of government power in the name of individual rights. Although the original 1787 document included a number of significant provisions of this kind-disallowing states from discriminating against residents of other states (Art. IV, $\$ 2$ ), prohibiting the imposition of any "religious test" as a qualification for federal office (Art. VI), proscribing bills of attainder and ex post facto laws (Art. I, $\$ 9$ ), and guaranteeing the right of habeas corpus except in certain cases of "rebellion or invasion" (Art. I, \$9)—its drafters thought the 
Constitution's primary protections for individual liberty lay in the checking and balancing structure of the national government (Brown 1991) and in the limitation of the new national government to a set of enumerated powers. Today, the best known and most enduringly controversial of the limitations on government authority are contained in the Bill of Rights and in the post-Civil War Amendments, most notably, the Fourteenth.

For at least two reasons, it can hardly be surprising that the content of such rights remains the subject of heated debate. First, the key beneficiaries of these provisions may include those whose social status or political clout makes it difficult for them to protect their interests through electorally accountable institutions. The claims such citizens make are likely to be unpopular. Second, the rights articulated are virtually always framed in broad terms that clearly signal a potential scope of applicability way beyond any specific understanding of their likely application at the time they were drafted. It has been argued-for example, by former judge Robert Bork (1989) and by current United States Supreme Court Associate Justice Antonin Scalia (1997: 47) — that courts should not limit majoritarian governance in the name of rights that were not clearly anticipated when the relevant constitutional text was adopted. Such a stance would require, however, that - to the degree that Americans remain intent on entrenching a robust understanding of individual rights in their constitution-the Constitution would have to be continually amended as changes in economic, social and political circumstances pose unanticipated issues. For individual rights, the exercise of which is likely to challenge majority sentiment, this seems highly problematic.

A profound, but indirect consequence of the Constitution's role in protecting individual rights is that the American Constitution, virtually from the founding, has provided a focus and a shape to a host of movements for social change. These include movements to amend the Constitution, for example, to guarantee women's suffrage or to give statehood to Washington, DC, as well as movements that insist that the Constitution, properly interpreted, would advance a social cause, such as abolitionism in the nineteenth Century or same-sex marriage now. ${ }^{8}$ At the moment, the proposal of new constitutional amendments seems a preferred political organizing tactic of conservatives-amendments to prohibit same-sex marriage, forbid abortion, or to authorize the criminalization of flag desecration are all of this type. There is emerging, however, a debate on the political left whether equivalent efforts ought not be mustered on behalf of stronger voting rights, guarantees of equal educational resources, and protections of such "safety net" features as publicly financed health care or housing (Jackson 2001).

The persistence of constitutional rhetoric as a leitmotif running through a such a wide array of political movements suggests the enormous power of a constitution

8 The leading history of the role of the United States Constitution in American culture is Kammen (1986). 
to channel political protest into largely peaceful forms and to significantly legitimate an existing regime, even as it holds out the promise of revolutionary challenge to the status quo (Powell 1986). The implicit premises of movements either to change a constitutional text or "improve" its interpretation are that constitutional entrenchment is an appropriate mechanism for protecting social values and that existing processes for constitutional change are worthy of pursuit. In the American system, such movements also imply the legitimating impact of judicial pronouncements concerning the constitutionality of government acts (Black 1969). Advocates of constitutional change tacitly recognize that, in the eyes of many Americans, court judgments upholding laws against constitutional challenge enhance their legitimacy. Thus, judicial interpretation is an essential target of movements to change what the Constitution says.

Although Americans are presumably inclined to believe that their freedom is enhanced by the constitutional entrenchment of individual liberties, the precise contribution of any constitution to the degree or quality of freedom that any society enjoys is not easy to assess. In the decades after the Civil War, the Fourteenth Amendment's guarantee of "equal protection of the laws" accomplished little for the African-Americans who were the Amendment's primary intended beneficiaries (Bell 1980: 30-8). Constitutional skeptics can cite the failure of challenges to the suppression of dissident speech and political activity around World War I or to the internment of Japanese-Americans during World War II as evidence of the Constitution's limited reliability. In an influential critique of the mid-1980s, Owen Fiss bemoaned the Supreme Court's more recent obliviousness in free speech disputes to the state's potential role in supporting and enriching public debate, frequently valuing the "autonomy" of wealthy or corporate interests over the access of individual citizens to meaningful, well-informed, politically robust discourse (Fiss 1986). Yet, it seems highly improbable that America's textual commitment to fundamental liberties is irrelevant to its success in maintaining a comparatively open society.

\section{Creating Affirmative Government OBLIGATIONS}

A fourth function of constitutions is to establish affirmative public welfare rights, and the United States Constitution is now among the minority that fails to acknowledge such rights explicitly. Yet, affirmative rights litigation is not unknown 
in American courts. Although it remains conventional wisdom that the United States Constitution does not create welfare rights that are enforceable in federal courts, many state courts have interpreted state constitutional provisions regarding public education as mandating not only a minimally adequate level of education, but also equity among school districts in the funding of public schools (Dayton and Dupree 2004).

There is some historical irony here. Those constitutions around the globe that protect social and economic rights may reflect the influence of the Weimar Constitution of 1919 or of socialist legal thought. It is also true, however, that many of the social rights provisions of post-World War II constitutions draw their inspiration from the rights discourse of the American New Deal, including Franklin Roosevelt's call for "the four freedoms" and "a second Bill of Rights" (Sunstein 2004). More recently, American constitutional theorists, most notably, Frank Michelman (1969) and William Forbath (1999 and 2001), have tried to argue that the United States Constitution, properly interpreted, actually does imply some minimal set of welfare rights as a precondition to meaningful citizenship. But, although the Warren Court in the 196os seemed to be edging towards that view, the Burger and Rehnquist Courts have been notably unsympathetic.

Where constitutions do not articulate social rights expressly, it is likely to be not just—or even primarily—-the absence of authorizing text, but rather anxieties about judicial enforcement of such rights that impedes their recognition. As recounted by Forbath (2004: 622-7), judges may regard social rights as too indeterminate to permit justiciability. They may entertain a related fear that the articulation and prospective enforcement of social welfare rights would tempt judges excessively to overstep the appropriate judicial role and to implement personal policy preferences in the guise of law. Judges may regard courts as lacking the competence to engage in the sensitive allocational trade-offs that social rights remedies could entail. They may regard judicial decision making about welfare rights, especially because of the potential budgetary impacts, as posing too great a set of constraints on the decisional authority of the elected branches of government. Relatedly, should unelected judges take too conspicuous a role in the allocation of social resources, the resulting incursion into the citizenry's role in self-governance may be seen by voters as too great a threat to overall democratic accountability.

Notwithstanding this list of objections, it is still worth noting that a number of constitutional courts around the globe have been enforcing social rights, as did, for example, the South African Constitutional Court in mandating that its government make broadly available a drug called Nevirapine, which inhibits the transmission of HIV/AIDS from pregnant women to their children (Tushnet 2004: 1906-1907). It may be that such courts regard the anti-social rights arguments as resembling closely those arguments against judicial review that have generally proved unpersuasive with regard to the enforcement of "classic" or "negative" 
constitutional rights. In addition, rights-protective courts may believe that the anxieties about the judicial articulation of social rights can be substantially addressed by acknowledging only relatively modest powers to enforce those rights through judicial decree. Mark Tushnet, for example, has noted what may be, in some systems, a preference for combining strong articulations of social entitlements with relatively weak judicial enforcement powers (Tushnet 2004).

\section{CONSTITUTIONAL INTERPRETATION AND CHANGE}

Constitutions cannot fulfill their functions simply by existing; they must be implemented. The foundational task in implementing a constitution is interpretation. Researchers have differed profoundly in their views as to the nature of the interpretive enterprise, and whether legal actors, most notably judges, are guided substantially in their constitutional judgments by what the Constitution says or rather by personal preferences external to the law.

The position that legal actors are wholly unconstrained by what a constitution says seems implausible; the rules that a constitution formally embodies surely do matter. For example, if the United States Constitution permitted Congress to oust Presidents on grounds more easily demonstrated than "high crimes or misdemeanors," the balance of powers between the elected branches of the federal government would surely be different than they are today. Likewise, if the text specifically stated, "Neither Congress, nor any state shall inflict a sentence of death for any crime," then the United States would have a different system of justice from the one that has developed under the more general proscription of "cruel and unusual punishment." Nonetheless, the relationship between constitutional text and the actual behavior of governments remains difficult to specify. Whether, for example, Britons enjoy materially less communicative liberty than do Americans because they lack a written Bill of Rights is debatable. ${ }^{9}$ We may wonder whether Japanese women enjoy greater equality than do American women, notwithstanding the provision of the Japanese Constitution that, "there shall be no discrimination in political, economic or social relations because of ... sex." Indeed, because of the likely gaps that exist everywhere between constitutional text and the realities of

9 The absence of a written Bill of Rights in Great Britain may be of especially tenuous significance since the United Kingdom became a signatory, in 1953, to the European Convention on Human Rights, which has been "a fruitful source of rights for the individual" (DeSmith and Brazier 1989: 426). 
governance, we might wish to prefer using the term "constitution" to mean a fundamental law as it is actually given life and meaning by the operation of all relevant institutional actors, or we might allow "constitution" to refer to the formal rules of the fundamental law, but acknowledge that the institutional impacts of constitutions cannot be ascertained simply by reading them. In either case-and they amount to much the same thing — the obvious starting point for appreciating how a constitution actually plays its role in society is examining interpretation, and most especially, the role of courts in interpreting constitutions and how that role relates to other processes of constitutional change.

\section{Modes of Argument}

When a legal dispute under the United States Constitution is properly presented for resolution to an American court, the process of interpreting the Constitution is a complex one. Judges face disagreement not only as to what various provisions of the Constitution mean, but even as to the methods most legitimately employed, both in general and in specific contexts, to discern such meaning. There are at least six varieties of argument that regularly appear in the written decisions of American courts interpreting the Constitution: historical arguments, textual arguments, structural arguments, ethical arguments, doctrinal arguments, and prudential arguments (Bobbitt 1984). In reviewing each category, the immediate point is not that any one method is sound, the best or even appropriate, but rather that it is indisputably available to American courts. Thus, in facing a constitutional challenge to any executive or legislative act, an ordinary court of general jurisdiction is acting in a manner consistent with conventional judicial practice in entertaining arguments along any of these lines in resolving how the Constitution applies.

Historical arguments generally appeal to what the drafters of particular constitutional provisions had in mind when they added relevant text to the Constitution-or, with perhaps more justification, what those who ratified various proposals believed they were ratifying. Arguments of this kind-championed prominently by such scholars as Richard Kay (1988) and Michael Perry (1996) are sometimes described as relying on "original intent." In the American system, the doctrine of judicial review is itself perhaps the most prominent example of this approach. Although the text of the Constitution is at best ambiguous on the point, there is little doubt that those who adopted the Constitution of 1787 expected that federal courts would have the power to void legislation not in conformity with the new document. It was not surprising that, in 1803 , the Supreme Court formally 
claimed the power to set aside federal statutes it deemed to exceed Congress's constitutional authorities, even though the Constitution nowhere expressly articulates the judiciary's power to do so. Moreover, the power of judicial review was "rapidly accepted" following the Supreme Court's Marbury decision ${ }^{10}$ (Nowak and Rotunda 2004: 11).

An important variation of historical argument is one that Lawrence Lessig has dubbed "fidelity as translation" (Lessig 1993). The core idea is that the modern judge should provide the constitutional text whatever contemporary reading will give the text the same meaning in its current context as it was intended to have in its original context (Lessig 1997: 1371). To take a fanciful example, consider that Art. I, section 8 of the Constitution allows Congress to create "an army" and "a navy." This would seem, linguistically, to exclude the prospect of "an air force." Imagine that we now have conclusive evidence that the founding generation had actually considered the prospect of human flight and were dead set against it as a breach of the natural order. Nonetheless, a modern judge should read the words "army" and "navy" to include "air force" because the framers intended the armed services clauses to allow for an adequate national defense and, once we are aware of their historic purpose, we should give the text a modern translation that is faithful to that purpose.

Yet another variation of historical argument may also appeal to long-standing institutional practice that may settle constitutional meaning even more definitely than any extant evidence of framer design. Thus, for example, it has been understood since the first Washington Administration that the Senate's power to give advice with regard to executive-negotiated treaties is to be rendered only after negotiations are complete, an interpretation that has prevailed chiefly because no one has since departed from this initial institutional precedent (Shane and Bruff 2005: 639).

Textual arguments appeal to the wording of constitutional text, although they may do so in different ways. An "originalist" textual argument would appeal to a proffered understanding of how the text would most likely have been understood at the time of its adoption. Thus, for example, a state might argue that the ban on "cruel and unusual punishment" should not be read in 2005 to proscribe capital punishment because, during the late eighteenth century, the death penalty would not have been understood to be "cruel and unusual." The best known proponent of this approach, both as a scholar and as a judge, is Associate Justice of the United States Supreme Court Antonin Scalia (1997).

A textual argument could also appeal, however, to the most reasonable current understanding of the text. For example, no one in the late eighteenth century could have envisioned an electronic wiretap, much less considered such a phenomenon covered by the constitutional use of the word "search." In 2005, however, anyone 
reading the protection against "unreasonable searches" would certainly expect the words to cover electronic forms of discovery, even without physical trespass on the subject's property. One could thus make a contemporary textual argument that the Constitution ought apply in such cases. ${ }^{11}$

Textual arguments of the originalist sort may seem the same as historical arguments based on original intent, but they depart when there is arguably a disjunction between what the drafters anticipated and the words actually used. For example, the text of the Constitution's Eleventh Amendment unambiguously precludes only federal lawsuits against a state that are "commenced or prosecuted" by citizens of another state or of a foreign state. Yet, the Supreme Court, in a series of sharply divided decisions, has ruled that the amendment signals a broader implicit historical understanding that states were not to be suable in state or federal court, without their consent, whether the plaintiffs are citizens of another state, of a foreign state, or of the defendant state itself (Mashaw, Merrill, and Shane 2003: 1260-8). In this context, the Court has favored the historical argument over the textual. ${ }^{12}$

Structural arguments make appeal to "inferences from the existence of constitutional structures and the relationships which the Constitution ordains among those structures" (Bobbitt 1984: 74). This method was given modern scholarly prominence with the work of Charles Black (1969), and is more recently exemplified in the writings of Akhil Amar (1999). A good example of the salience of structural argument arose during the impeachment trial of President Clinton. President Clinton's trial had proceeded under the conventional understanding that the Senate could try him only for "high crimes or misdemeanors," and that conviction would necessarily entail removal from office. Some of his political opponents, however, foreseeing that he would not be removed from office, argued that it would be consistent with the constitutional text to recognize Senate authority to convict the President for any offense, including forms of wrongdoing that would not amount to "high crimes or misdemeanors." Conviction of the President for something less than a "high crime or misdemeanor" would simply entail some penalty less onerous than removal.

The Senate never appeared to take this possibility seriously. One of the most telling arguments against it was presumably that the tripartite structure of the federal government into three co-equal branches intended a kind of equilibrium that would be unbalanced should one branch, the legislative, have the capacity to

\footnotetext{
11 This modernist "take" on constitutional text is likely to produce results identical to Lawrence Lessig's view of "fidelity in translation," discussed above. The key difference is that Lessig's view puts interpretive emphasis on the framers' historical purposes, and a modern textualist is emphasizing the sense of the text to the modern mind. The modern sense of the text, however, is likely to resonate well with the text's broad historical purposes.

12 And there is a strong argument that the Supreme Court got the Eleventh Amendment history wrong (Hovenkamp 1996).
} 
discipline the head of another, the executive, on any grounds of its choosing. This inference, based on structure, likely settles the matter of proper interpretation.

Ethical argument, an approach most prominently identified with Ronald Dworkin (1996), is an argument that seeks to impute to constitutional text its most morally attractive plausible meaning. Perhaps the most celebrated Supreme Court decision seemingly based on such an argument occurred in a case called Bolling vs. Sharpe (347 U.S. 497, 1954), which invalidated mandatory racial segregation in the public schools in the District of Columbia. On the same day, in a series of cases consolidated as Brown vs. Board of Education (347 U.S. 483, 1954), the Court had held that the Fourteenth Amendment guarantee of "the equal protection of the laws" invalidated mandatory racial segregation in the public schools of states. Because the District of Columbia is not a state, however, but a federal district, the Fourteenth Amendment did not apply. The Fifth Amendment, which gives to the residents of the federal district an equivalent textual guarantee of "due process of law," does not mention equal protection. Nonetheless, the Court in Bolling extended the law of Brown to the District of Columbia. The Court said simply that there could be no legitimate justification for the legally compelled segregation of the races-seemingly, a straightforward moral argument. Implicitly, the Court was also rejecting as illegitimate the prospect that racial segregation should be legally permitted in the United States only in the national capital, which would have been a morally repugnant result.

Over the years, of course, judicial decisions based on all the categories of argument just catalogued will necessarily take on a jurisprudential life of their own (Strauss 1996). Especially in a common law system, one would thus expect that, over time, constitutional disputes will begin to be resolved in ways that seek to adduce decisional principles from decided precedents, rather than from constitutional text alone. This gives rise to a fifth mode of argument, "doctrinal." For example, no United States Supreme Court decision of recent decades has stirred more heated battle than Roe vs. Wade (410 U.S. 113, 1973), the decision that invalidated most state laws barring abortion in the first two trimesters of a woman's pregnancy. The opinion is written, however, chiefly as a straightforward doctrinal argument. In earlier decisions, the Court had held both that a constitutionally implicit right to privacy protects a married couple's right to acquire contraception and that the guarantee of equal protection implicitly extends that right to unmarried persons. For the Roe majority, it hardly seemed a stretch to extend the right of privacy to include the decision whether to terminate pregnancy. The Court likewise insisted, based also on earlier cases, that states enjoy authority to regulate for the protection of maternal and child health, as well as for the safe practice of medicine, even if there would be some resulting burden on a woman's capacity to choose abortion.

Professor Bobbitt recognizes a sixth category of argument, which he terms, "prudential," namely, "constitutional argument which is actuated by the political 
and economic circumstances surrounding the decision" (Bobbitt 1982: 61). It is a form of argument identified most strongly with the work of the late Alexander Bickel (1962.) Among the most notable examples of prudential arguments are those, which may also be a variety of structural argument, that persuade the federal courts that certain questions are beyond their purview. For example, albeit without producing a majority opinion, the Supreme Court in Goldwater vs. Carter (444 U.S. 996, 1979), refused to rule whether the President was legally entitled, without either express statutory authority or Senate advice and consent, to withdraw from the Mutual Defense Treaty with the Republic of China (Taiwan), a necessary precursor to awarding diplomatic recognition to the Chinese government in Beijing. ThenJustice Rehnquist, writing for a plurality, determined that anxieties about the potential real-world consequences should federal courts interfere with the elected branches' control of US foreign policy counseled for a determination that treaty termination questions are beyond the courts' jurisdiction.

\section{INTERPRETATION AND LEGITIMACY}

The anxieties of opponents of judicial review are, of course, only intensified by the rich menu of interpretive possibilities that this analysis exposes. Champions of any of these forms of argument will find ample precedent for their use in the records of past constitutional decisions. It hardly requires hindsight to spot the inevitability that a constitutional law germinated through such a broad spectrum of arguments-especially arguments other than those based on "original intent" and "original meaning"-is likely to induce substantial changes in constitutional meaning over time. Because the United States Constitution, as do presumably all Constitutions, explicitly specifies processes for its amendment, the legitimacy of constitutional change effected through other means is open to question.

The various responses of constitutional theorists to this legitimacy challenge have tended to fall within one of three types. First, the legitimacy challenge seems to posit that the imposition of constitutional constraints are legitimate only if envisioned by the drafters or ratifiers of the relevent text. Yet, there is also reason to think that the original drafters or ratifiers imagined that change would occur along the lines that the country has witnessed. That is, even though earlier generations might not have specifically anticipated the results of particular challenges-for example, that the ban on cruel and unusual punishments would invalidate the death penalty for minors or that the equal protection clause would outlaw legally mandated race segregation-the ways in which these changes have occurred, 
through the procedurally acceptable application of conventional techniques of legal interpretation, would have themselves been acceptable to the framers (Powell 1985).

A second line of argument is pragmatist, positing that the test of legitimacy, to paraphrase Oliver Wendell Holmes, is experience, not logic. The Constitution of the United States declares a variety of purposes including the establishment of justice, the insurance of "domestic tranquility," the promotion of the "general welfare," and the securing for posterity of "the blessings of liberty." In this light, a pragmatist would argue that the legitimacy of the judicial function as it has actually been performed ought to be tested by whether that function has actually aided in the Constitution's accomplishment of those purposes. So long as the public continues to have confidence in its courts, so long as the United States continues to enjoy commendable levels of peace, security, justice, and liberty, the making of constitutional law ought to be viewed as legitimate.

A third line of argument roots both the objections to judge-led constitutional change and to its defense in democratic theory. From a democratic standpoint, the defect of constitutional change wrought by unelected judges is the implicit departure from the ideal of popular sovereignty, namely, that "the people," most often through their elected representatives, should be the authors of the laws that bind them. ${ }^{13}$ Constitutional constraints are legitimately imposed upon current political authorities only because "the people" ordained the Constitution. To permit changes to the Constitution through processes other than those "the people" themselves prescribed through the Constitution is to undermine popular self-governance.

Responses to this line of argument that are rooted in democratic theory take different forms. Bruce Ackerman, for example, accepts that some form of popular ratification is necessary to legitimate constitutional change that occurs other than through the formally prescribed constitutional amendment process. Retracing our history, he asserts that constitutional change may legitimately occur when triggered by the enactment of "transformative statutes," through which the elected branches place their imprimatur on a constitutional understanding at odds with contemporary constitutional law (Ackerman 1991: 268). Based on such statutes, a court may choose to alter its understanding of constitutional law if intervening elections signal that the people, through their civic deliberation, have demonstrated adequate public support for a de facto amendment of the Constitution. Ackerman's paradigm case is the Court's New Deal decisions greatly expanding the reach of Congress's regulatory authorities under the Commerce Clause.

Another line of theory, also resting on the premise that equates democratic legitimacy with popular sovereignty, argues that the courts nonetheless have a significant role in reinforcing democratic rule. Pursuant to this line of thought,

13 The history of legal thought regarding this so called 'counter-majoritarian' difficulty is exhaustively traced in Friedman (2000). 
forcefully argued by the late John Hart Ely (1980), a paradigm example of legitimate judicial creativity would be the reapportionment cases, in which the Supreme Court forced state legislatures to redesign electoral districts on a "one person, one vote" basis. Such a result might be hard to square with an historical reading of the Constitution, but would be legitimate, in Ely's view, because the result of the decisions was to expand the people's capacity to govern themselves fairly through their elected representatives.

There is, however, yet a third brand of democratic theory that starts by challenging both the metaphor of popular sovereignty and the practical equation of democracy with electoral accountability (Shane 2004a). Under this view, what legitimates democratic governance are really two things: the degree to which citizens enjoy opportunities to act meaningfully in choosing their political fate and the degree to which the system fosters the equal consideration of the interests of all persons in decision making that affects the public at large. Elections are an important part of this equation; they obviously provide the focus for much of what people experience as autonomous political activity. But they cannot be everything. A system cannot be legitimate, whatever its electoral rules, if the interests of some are universally disregarded in favor of the interests of others, regardless of the equity of their claims. From this point of view, constitutional law-making in the courts functions, in part, to energize a legitimacy-enforcing dialogue with the elected branches. The function of this dialogue is to give voice to interests and to public values that, for structural reasons, the elected branches might be expected in some systemic way to overlook or underweigh. ${ }^{14}$ The net result, echoing James Madison's theory in the famous Federalist Papers, No. 10, is to help insure that law is driven by the public interest, rather than by merely private interest or the passion of the moment.

Closely related to these debates over the legitimacy of judicial review is the related, but distinct question of judicial supremacy-the degree to which constitutional interpretation uttered by the courts should be deemed the "final say." There is currently in the United States a significant debate, both empirical and normative, on the role of "popular constitutionalism." 15 The questions are the degree to which institutions outside the courts are also responsible for constitutional meaning and to what degree they should be so. The debate admits of a host of positions; some scholars who believe that legislatures and executives share authority to interpret the Constitution nonetheless embrace judicial review, while others do not. This is a slippery debate because it is not clear exactly what

\footnotetext{
14 A great deal has been written arguing that constitutional review by unelected judges can convincingly be viewed as part of a democracy-reinforcing dialogue with the elected branches of government. Important writers in this vein include Fisher (1988) and Eisgruber (2001).

15 Major new works in this vein are pouring forth and key examples include: Johnsen 2004; Kramer 2004; Kramer et al. 2005; and Tushnet 1999.
} 
judicial supremacy consists of. When legislatures perceive judicial pronouncements to be out of step with popular feeling, they frequently respond by enacting new statutes that can be distinguished only minimally from others already held unconstitutional. That happens with seeming frequency on the subjects of abortion and church-state relations. Whether or not this is a wise use of legislative time, it would seem hard to dismiss as illegitimate. A harder question might be whether executive or legislative authorities should be deemed to act unlawfully or illegitimately if they persist in precisely those behaviors or enactments that, as to other parties or in other forms, the courts have already ruled against them. It is true enough that such defiance, at least since the desegregation of America's public schools, is exceedingly rare. But this seems less to be the result of any well-understood legal doctrine of judicial supremacy than a popular expectation that legislatures will not act defiantly to this degree.

An intriguing question is whether constitutions that are easier to amend through their formally specified processes witness less change through informal interpretation by nonjudicial actors. Although there do not appear to be any rigorous attempts at a quantitative assessment, one political scientist has recently verified that what he calls "informal political construction" of constitutions does occur in the American states, even though state constitutions are notably easier to amend than is the federal (Besso 2005). Informal change processes may thus be an important subject of study with regard to all constitutions.

\section{Directions for Future Research}

It is quite unlikely that the debates of two centuries over a constitution's roles and the ways in which legal actors properly implement those roles are going to subside. Moreover, because of both intellectual trends and the press of historical events, it is likely that at least the following half dozen avenues of intellectual inquiry will engage even greater attention in the coming decades' debates over constitutional analysis.

One is the subject of comparative constitutional analysis, which is almost entirely beyond the domain of this chapter. The wave of democratic reform in the newly constituted states of the former Soviet Union, in Africa, and perhaps in the Middle East has created a significant cottage industry among legal experts seeking to identify how various extant constitutions and their various provisions for the structure of government and protection of individual rights have actually fared and why (Horowitz 2002). There is no evidence of that trend subsiding. 
Relatedly, there is likely to be exciting research done on the relationship between constitutions and the mediation of ethnic conflict. On this subject, the American lens through which this chapter has been written is concededly too narrow. The generation of Americans who drafted, debated, and enjoyed authority to help ratify the United States Constitution were a relatively homogeneous bunch. Although the Constitution would prove to have profound consequences for Native Americans and for African-Americans, there was no thought given in 1787 to "power sharing" with either. By contrast, power sharing in ethnically divided states is perhaps the paramount challenge facing drafters of new constitutions in the twenty-first century. There is deep debate over the appeal of what has come to become "consociational democracy," namely, some form of constitutional arrangement in which different ethnic groups share executive power proportionally, enjoy substantial group autonomy, and rely on consensus for a significant portion of government decision making (compare Lijphart 2002 with Horowitz 2002). Such decisions could be classed, if we follow the list of functions noted above, as "implementing key founding bargains," but the relationship of constitutionalism to inter-ethnic cooperation is so complex a subject that a much more fine-grained picture of constitutional elements would be necessary to do justice to it.

A third project, fed by the first two, is likely to be an intensification of interest in the relationship between constitutionalism and democratic theory. The global proliferation of new constitutional activity, on both the national and supranational level (consider the European Union), coincides with the rapid growth of interactive information and communications technologies that can conceivably facilitate wholly novel institutional forms and processes through which citizens may engage with one another and with the state in relation to public policy making (Shane 2004b). Researchers are only beginning to explore the implications of these new technologies for democratic theory and practice, and it is easy enough to predict that ongoing developments in democratic theory and constitutional design will cross-pollinate significantly over the coming decades.

A fourth project of continuing interest is likely to be the effort, noted at the outset of this chapter, to synthesize internal and external accounts of constitutional interpretation to provide a more fully effective model than either can provide alone (Feldman 2005). The increasing interest among law faculties in interdisciplinary inquiry, accompanied by the increasing receptiveness among political scientists to accounts of judicial behavior more nuanced than the pure attitudinal model, should help accelerate this development.

Fifth, and related to the growth of interdisciplinary inquiry, we are likely to see a greater role for cognitive and decision psychology in exploring how legal actors fulfill their roles. Research on bias, attitudes, and stereotypes is likely to inform debates about how judges interpret the law and whether there exist structures, processes, or techniques effective in limiting the role of individual bias in legal interpretation (Ferguson, Babcock, and Share 2005). Similarly, given the significant 
prominence of critical legal studies, feminism, and critical race studies in the United States, there is likely to be continuing interest in possible psychological mechanisms through which legal interpretation may operate to reinforce social hierarchies based on wealth, gender, race, or, indeed, all of the above.

Finally, and as challenging as any of the other subjects, legal scholarship is paying increasing attention to the role of actors other than judges in giving meaning to the Constitution. Far more often than constitutional disputes reach the judiciary, the elected branches of federal and state governments are required, in the course of implementing their official responsibilities, to determine what the Constitution means. In many cases-perhaps most notably, at the federal level, with regard to the proper allocation of war powers between Congress and the President-the issues presented are unlikely ever to be addressed, much less resolved in judicial proceedings. The role of the Constitution in such settings, the relationship, both normative and empirical, between judicial interpretations and "extra-judicial" interpretations of the Constitution (Shane 1987), and the impacts, if any, of extra-judicial interpretations on public understanding of constitutional meaning are all subjects ripe for both empirical and theoretical investigation. These are also frontiers that, among political scientists, appear to be all but unexplored.

\section{REFERENCES}

Ackerman, B. 1991. We the People, I: Foundations. Cambridge: Harvard University Press. Amar, A. R. 1999. Intratextualism. Harvard Law Review, 112: 747-827.

Bell, D. 1980. Race, Racism and American Law 2nd edn. Boston: Little, Brown and Company.

Besso, M. 2005. Constitutional Amendment Procedures and the Informal Political Construction of Constitutions. Journal of Politics, 67: 69-87.

Best, J. 2004. Presidential Selection: Complex Problems and Simple Solutions. Political Science Quarterly, 119: 39-59.

Bickel, A. 1962. The Least Dangerous Branch. New Haven: Yale University Press.

BLACK, C. L. 1969. Structure and Relationship in Constitutional Law. Baton Rouge: Louisiana State University Press.

Boввітт, P. 1982. Constitutional Fate: A Theory of the Constitution. New York: Oxford University Press.

Bork, R. 1989. The Tempting of America. New York: Free Press.

Brown, R. 1991. Separated Powers and Ordered Liberty. University of Pennsylvania Law Review, 139: 1513-66.

Calabresi, S. G. 1995. "A Government of Limited and Enumerated Powers": In Defense of United States v. Lopez. Michigan Law Review, 94: 752-831.

- and Prakash, S. B. 1994. The President's Power to Execute the Laws. Yale Law Journal, 104: 541-665.

Chemerinsky, E. 1995. The Values of Federalism. Florida Law Review, 47: 499-540. 
Choper, J. 1980. Judicial Review and the National Political Process. Chicago: University of Chicago Press.

Dayton, J. and Dupre, A. 2004. School Funding Litigation: Who's Winning the War? Vanderbilt Law Review, 57: 2351-413.

DeSmith, S. and Brazier, R. 1989. Constitutional and Administrative Law 6th edn. London: Penguin.

Dworkin, R. 1977. Taking Rights Seriously. Cambridge: Harvard University Press.

1996. Freedom's Law: The Moral Reading of the Constitution. Cambridge: Harvard University Press.

Edwards III, G. C. 2004. Why the Electoral College is Bad for America. New Haven: Yale University Press.

Eisgruber, C. L. 2001. Constitutional Self-Government. Cambridge: Harvard University Press.

Ely, J. H. 1980. Democracy and Distrust: A Theory of Judicial Review. Cambridge: Harvard University Press.

FARINA, C. R. 1998. Undoing the New Deal Through the New Presidentialism. Harvard Journal of Law \& Public Policy, 22: 227-38.

Feldman, S. M. 2005. The Rule of Law or the Rule of Politics? Harmonizing the Internal and External Views of Supreme Court Decision Making. Law and Social Inquiry, 30: 89-135.

Ferguson, J. R., Babcock, L., and Shane, P. M. 2005. The Subconscious Influence of Policy Preferences on Constitutional Reasoning. (Manuscript under submission for publication, available from authors.)

Fisher, L. 1971. The Efficiency Side of Separated Powers. Journal of American Studies, 5: $113-31$.

— 1988. Constitutional Dialogues: Interpretation as Political Process. Princeton: Princeton University Press.

FIss, O. 1986. Free Speech and Social Structure. Iowa Law Review, 71: 1405-25.

Flaherty, M. S. 1996. The Most Dangerous Branch. Yale Law Journal, 105: 1725-839.

Forbath, W. E. 1999. Caste, Class, and Equal Citizenship. Michigan Law Review, 98: 1-91.

- 2001. The New Deal Constitution in Exile. Duke Law Journal, 51: 165-222.

- 2004. Not So Simple Justice: Frank Michelman on Social Rights, 1969-Present. Tulsa Law Review, 39: 597-638.

Friedman, B. 2002. The Birth of an Academic Obsession: the History of the Countermajoritarian Difficulty, Part Five. Yale Law Journal, 112: 153-259.

Gillman, H. 1993. The Constitution Besieged: The Rise and Demoise of Lochner Era Police Powers Jurisprudence. Durham: Duke University Press.

— and Clayton, C. W. (eds) 1999. Supreme Court Decision-Making: New Institutionalist Approaches. Chicago: University of Chicago Press.

Graber, M. A. 2002. Constitutional Politics and Constitutional Theory: A Misunderstood and Neglected Relationship. Law \& Social Inquiry, 27: 309-38.

Greene, A. S. 1994. Checks and Balances in an Era of Presidential Lawmaking. University of Chicago Law Review, 61: 123-96.

Horowitz, D. 2002. Constitutional Design: Proposals versus Processes. In The Architecture of Democracy: Constitutional Design, Conflict Management, and Democracy, ed. A. Reynolds. Oxford: Oxford University Press.

Hovenkamp, H. 1996. Judicial Restraint and Constitutional Federalism: The Supreme Court's Lopez and Seminole Tribe Decisions. Columbia Law Review, 96: 2213-47. 
Jackson, Jr., J. L. 2001. Toward a More Perfect Union: Advancing New American Rights. New York: Welcome Rain Publishers.

Johnsen, D. 2004. Functional Departmentalism and Nonjudicial Interpretation: Who Determines Constitutional Meaning? Law and Contemporary Problems, 67: 105-47.

Kagan, E. 2001. Presidential Administration. Harvard Law Review, 114: 2245-385.

Kammen, M. 1986. A Machine That Would Go of Itself: The Constitution in American Culture. New York: Vintage Books.

KAY, R. S. 1988. Adherence to the Original Intentions in Constitutional Adjudication: Three Objections and Responses. Northwestern University Law Review, 82: 226-92.

Kramer, L. D. 200o. Putting the Politics Back into the Political Safeguards of Federalism. Columbia Law Review, 100: 215-93.

2004. The People Themselves: Popular Constitutionalism and Judicial Review. New York: Oxford University Press.

— , Sager, L. G., Fleming, J. E., Greene, A. S., Kaczarowski, R. J., Saiger, A. and Zipursky, B. C. 2005. Symposium: Theories of Taking the Constitution Seriously Outside the Courts. Fordham Law Review, 73: 1343-476.

Krotoszynski, Jr., R. J. 1994. Brind and Rust v. Sullivan: Free Speech and the Limits of a Written Constitution. Florida State University Law Review, 22: 1-34.

LaPierre, B. 1982. The Political Safeguards of Federalism Redux: Intergovernmental Immunity and the States as Agents of the Nation. Washington University of Law Quarterly, 60: 779-1056.

Lessig, L. 1993. Fidelity in Translation. Texas Law Review, 71: 1165-268.

- 1997. Fidelity as Translation. Fordham Law Review, 65: 1365-433.

- and Sunstein, C R. 1994. The President and the Administration. Columbia Law Review, 94: 1-123.

Lijphart, A. 2002. The Wave of Power-Sharing Democracy. In The Architecture of Democracy: Constitutional Design, Conflict Management, and Democracy, ed. A. Reynolds. Oxford: Oxford University Press.

McConnell, M. W. 1987. Federalism: Evaluating the Founders' Design. University of Chicago Law Review, 54: 1484-512.

Marks, Jr., T. C. and Cooper, J. F. 2003. State Constitutional Law. St. Paul: Thomson-West.

Marshall, W. 1998. American Political Culture and the Failures of Process Federalism. Harvard Journal of Law \& Public Policy, 22: 139-55.

Mashaw, J. R., Merrill, R. A., and Shane, P. M. 2003. Administrative Law: The American Public Law System. St. Paul: Thomson-West.

Merritt, D. J. 1994. Three Faces of Federalism: Finding a Formula for the Future. Vanderbilt Law Review, 47: 1563-85.

Michelman, F. I. 1969. Foreword: On Protecting the Poor through the Fourteenth Amendment. Harvard Law Review, 83: 7-59.

Miller, G. P. 1986. Independent Agencies. Supreme Court Review, 1986: 41-97.

North, D. C. 1990. Institutions, Institutional Change and Economic Performance. New York: Cambridge University Press.

Nowak, J. E. and Rotunda, R. D. 2004. Constitutional Law 7th edn. St.Paul: Thomson-West.

Perry, M. J. 1996. The Constitution in the Courts: Law or Politics? New York: Oxford University Press.

Pinello, D. 1999. Linking Party to Judicial Ideology in American Courts: A Meta-analysis. Justice System Journal, 20: 219-54. 
Powels, H. J. 1985. The Original Understanding of Original Intent. Harvard Law Review, 98: $885-948$.

1986. Parchment Matters: A Meditation on the Constitution as Text. Iowa Law Review, 71: $1427-35$.

Rakove, J. 2004. Presidential Selection: Electoral Fallacies. Political Science Quarterly, 119: 21-37.

Rosenfeld, M. 1994. Modern Constitutionalism as Interplay Between Identity and Diversity. In Constitutionalism, Identity, Difference and Legitimacy, ed. M. Rosenfeld. Durham: Duke University Press.

Rubin, E. L. and Feeley, M. 1994. Federalism: Some Notes on a National Neurosis. UCLA Law Review, 41: 903-52.

SArgentich, T. O. 1993. The Administrative Process in Crisis-The Example of Presidential Oversight of Agency Rulemaking. Administrative Law Journal of the American University, 6: $710-20$.

Sartori, G. 1994. Comparative Constitutional Engineering: An Inquiry into Structures, Incentives and Outcomes. New York: New York University Press.

SCALIA, A. 1997. A Matter of Interpretation: Federal Courts and the Law. Princeton: Princeton University Press.

Segal, J. A. and Spaeth, H. J. 1993. The Supreme Court and the Attitudinal Model. New York: Cambridge University Press.

Shane, P. M. 1987. Legal Disagreement and Negotiation in a Government of Laws: The Case of Executive Privilege Claims Against Congress. Minnesota Law Review, 71: 461-542.

— 1993. Who May Remove or Discipline Federal Judges? A Constitutional Analysis. University of Pennsylvania Law Review, 142: 209-42.

- 1995. Political Accountability in a System of Checks and Balances: The Case of Presidential Review of Rulemaking. Arkansas Law Review, 48: 161-214.

2000. Federalism's “Old Deal”: What's Right and Wrong With Conservative Judicial Activism. Villanova Law Review, 45: 201-43.

2003. When Interbranch Norms Break Down: Of Arms-for-Hostages, "Orderly Shutowns," Presidential Impeachments, and Judicial Coups. Cornell Journal of Law \& Public Policy, 12: 503-42.

- 2004a. The Electronic Federalist: The Internet and the Eclectic Institutionalization of Democratic Legitimacy. In Democracy Online: The Prospects for Political Renewal through the Internet, ed. P. M. Shane. New York: Routledge.

— (ed.) 2004b. Democracy Online: The Prospects for Political Renewal through the Internet. New York: Routledge.

- and Bruff, H. H. 2005. Separation of Powers Law: Cases and Materials 2nd edn. Durham: Carolina Academic Press.

Shapiro, D. L. 1995. Federalism: A Dialogue. Chicago: Northwestern University Press.

Smith, R. M. 1988. Political Jurisprudence, the New Institutionalism, and the Future of Public Law. American Political Science Review, 82: 89-108.

Strauss, D. A. 1996. Common Law Constitutional Interpretation. University of Chicago Law Review, 63: 877-935.

Strauss, P. L. 1997. Presidential Rulemaking. Chicago-Kent Law Review, 72: 965-86.

Sunstein, C. R. 2004. The Second Bill of Rights: FDR'S Unfinished Revolution and Why We Need It More than Ever. New York: Basic Books.

Tushnet, M. 1999. Taking the Constitution Away from the Courts. Princeton: Princeton University Press. 
2004. Social Welfare Rights and the Forms of Judicial Review. Texas Law Review, 82: 1895-919.

Van Alstyne, W. 1985. The Second Death of Federalism. Michigan Law Review, 83: 1709-33. Wechsler, H. 1954. The Political Safeguards of Federalism: The Role of the States in the Composition and Selection of the National Government. Columbia Law Review, 54: 54360 .

Whittington, K. E. 2000. Once More Unto the Breach: Postbehavioralist Approaches to Judicial Politics. Law \& Social Inquiry, 25: 601-34.

Yoo, J. 1997. The Judicial Safeguards of Federalism. Southern California Law Review, 70: 1311-405. 